Kamil Dybiec

Uniwersytet im. Adama Mickiewicza w Poznaniu

\title{
ROLA LOKALNEJ ADMINISTRACJI PUBLICZNEJ W ZAKRESIE OCHRONY POWIETRZA NA PRZYKŁADZIE JELENIEJ GÓRY
}

\section{Wprowadzenie}

W końcu lat 70. XX w. w okolicach Jeleniej Góry, w Karkonoszach, doszło do katastrofy ekologicznej spowodowanej opadami tzw. kwaśnych deszczy, których przyczyną były przemysłowe emisje zanieczyszczeń z polskich, niemieckich i czeskich elektrowni opalanych węglem brunatnym. Efekty zniszczenia lasów Karkonoszy widoczne są na stokach górskich po dzień dzisiejszy. Kwaśne deszcze i wywołane przez nie zniszczenia obrazują, jak ważna jest ochrona powietrza i jak ważne jest uwzględnianie potrzeb ochrony środowiska w rozwoju gospodarczym oraz społecznym. Przedmiotem niniejszego artykułu jest zwięzły przegląd zadań i kompetencji lokalnej administracji publicznej w zakresie ochrony powietrza na przykładzie Jelenie Góry, tj. lokalnych organów administracji rządowej: Wojewódzkiego Inspektora Ochrony Środowiska, Regionalnego Dyrektora Ochrony Środowiska, organów samorządowych oraz Wojewódzkiego Funduszu Ochrony Środowiska i Gospodarki Wodnej.

\section{Zanieczyszczenie powietrza w Jeleniej Górze i jego przyczyny}

Jelenia Góra jest czwartym pod względem liczby ludności (83 tys. mieszkańców, wg danych GUS, 2012), ${ }^{1}$ a drugim pod względem powierzchni $\left(109 \mathrm{~km}^{2}\right)$ miastem na Dolnym Śląsku. ${ }^{2}$ Położona jest w Kotlinie Jeleniogórskiej, otoczonej $\mathrm{z}$ wszystkich stron wzniesieniami. Takie położenie geograficzne utrudnia wymianę

\footnotetext{
1 Główny Urząd Statystyczny, Ludność. Stan i struktura w przekroju terytorialnym. Stan w dniu 30 VI 2012 r.; http:// www.stat.gov.pl/cps/rde/xbcr/gus/l_ludnosc_stan_struktura_30062012.pdf (dostęp: 15.04.2013 r.).

2 Dane według Banku Danych Lokalnych publikowanego przéz Główny Urząd Statystyczny, http://www.stat.gov.pl/ bdl/app/strona.html?p_name=indeks (dostęp: 15.04.2013 r.).
} 
mas powietrza i sprzyja kumulowaniu się zanieczyszczeń. W Jeleniej Górze, na obszarze uzdrowiska Cieplice zlokalizowana jest należąca do Wojewódzkiego Inspektoratu Ochrony Środowiska we Wrocławiu stacja pomiaru powietrza, dzięki której badany jest poziom zanieczyszczenia powietrza. W szczególności monitorowany jest poziom stężenia dwutlenku siarki, dwutlenku azotu, tlenku azotu, tlenku węgla, ozonu i pyłu zawieszonego PM10. Monitoring powietrza w ostatnich latach wskazywał na przekroczenie dopuszczalnych norm stężenia pyłu zawieszonego PM10, jak również tlenku węgla, a także wysoki poziom tlenków azotu w powietrzu. ${ }^{3}$ Dłuższe oddziaływanie wysokich poziomów zanieczyszczeń powoduje określone dolegliwości u ludzi, w szczególności pył zawieszony może wywoływać choroby skóry czy zapalenie dolnych dróg oddechowych, tlenki azotu zapalenie oskrzeli i zapalenie płuc, a tlenek węgla ogólne osłabienie, bóle i zawroty głowy. ${ }^{4}$

Głównymi, antropogenicznymi źródłami emisji tlenku węgla oraz cząstek stałych PM10 są: spalanie paliw (węgla i ropy naftowej), szczególnie w przemyśle energetycznym, hutniczym i chemicznym, spaliny samochodowe oraz spalanie węgla na potrzeby produkcji ciepła w sektorze gospodarczo-bytowym. Uchwalony przez Sejmik Województwa Dolnośląskiego Program Ochrony Powietrza dla Jeleniej Góry ${ }^{5}$ wskazuje, że w 2009 r. zdecydowana większość emisji tlenku węgla w powietrzu w Jeleniej Górze miała charakter napływowy. Pochodziła głównie ze źródeł zlokalizowanych na terenie Niemiec i Czech (471,7 tys. ton), jak również z terytorium Polski ze źródeł oddalonych od Jeleniej Góry o ponad $30 \mathrm{~km} .{ }^{6}$ Całkowita emisja napływowa tlenku węgla wyniosła blisko 630 tys. ton, podczas gdy całkowita emisja ze źródeł zlokalizowanych w Jeleniej Górze 6,5 tys. Tak duża dysproporcja pomiędzy ilością napływowej oraz miejscowej emisji CO pozwala postawić tezę, że ochrona powietrza (przynajmniej w zakresie przeciwdziałania wysokim stężeniom CO) nie jest zadaniem, które skutecznie można realizować na szczeblu lokalnym czy nawet krajowym, ale wymaga ona podjęcia środków zaradczych na szczeblu międzynarodowym. Nie oznacza to bynajmniej, iż podejmowanie lokalnych działań ochronnych pozbawione jest znaczenia, natomiast żeby przyniosły one spodziewany efekt, powinny stanowić część działań podejmowanych na większym obszarze.

Głównym miejscowym źródłem emisji tlenku węgla w 2009 r. była emisja powierzchniowa, tj. emisja z ogrzewania indywidualnego (ponad 86\%) i liniowa, tj.

3 Wyniki pomiarów powietrza dokonywanych w województwie dolnośląskim, publikowane przez Wojewódzki Inspektorat Ochrony Środowiska we Wrocławiu; http://air.wroclaw.pios.gov.pl/ (dostęp: 15.04 .2013 r.).

4 A. Badyda, Analiza i ocena efektów oddziaływania wybranych uciążliwości ruchu drogowego na środowisko miejskie w Warszawie, Warszawa 2006, s. 37-50; http://bcpw.bg.pw.edu.pl/Content/2950/Praca+doktorska,+Artur+Badyda,+wersja+ostateczna.pdf (dostęp: 15.04.2013 r.).

Uchwała nr XX/468/12 Sejmiku Województwa Dolnośląskiego z dnia 9 lutego 2012 r. w sprawie zmiany uchwały nr III/44/10 Sejmiku Województwa Dolnośląskiego z dnia 28 grudnia 2010 r. w sprawie przyjęcia „Naprawczych programów ochrony powietrza dla stref na terenie województwa dolnośląskiego, w których zostały przekroczone poziomy dopuszczalne i docelowe substancji w powietrzu." (Dz. Urz. Województwa Dolnośląskiego z dnia 6.03.2013 r., poz. 940). 
Rola lokalnej administracji publicznej w zakresie ochrony powietrza...

emisja komunikacyjna (ponad 11\%). Tymczasem udział emisji punktowej, tj. emisji z ciepłowni, wynosił zaledwie 2,5\%. ${ }^{7}$ Wobec powyższego, z uwagi na sezon grzewczy, wysokie poziomy zanieczyszczeń notowane są zwłaszcza w miesiącach zimowych (od listopada do marca). ${ }^{8}$ Lokalne działania nakierowane na ochronę powietrza powinny zatem uwzględniać miejscowe źródła emisji zanieczyszczeń. W Programie Ochrony Powietrza dla Jeleniej Góry zapisano, iż zakres działań niezbędnych do przywrócenia standardów jakości powietrza w zakresie tlenku węgla i pyłu PM10 dla emisji powierzchniowej powinien obejmować w szczególności:

- rozbudowę centralnego systemu zaopatrzenia w energię cieplną,

- zmianę paliwa na gaz, olej opałowy, energię elektryczną i odnawialne źródła energii,

- zmniejszenie zapotrzebowania na energię cieplną poprzez ograniczanie strat ciepła (termomodernizację budynków);

dla emisji liniowej:

- całościowe, zintegrowane planowanie rozwoju systemu transportu na terenie miasta,

- upłynnianie potoków ruchu publicznego,

- kontynuację modernizacji taboru komunikacji autobusowej,

- bieżącą modernizację dróg i rozbudowę systemu ścieżek rowerowych,

- wprowadzanie zieleni ochronnej wzdłuż ciągów drogowych i kolejowych; natomiast dla emisji punktowej:

- optymalne sterowanie procesem spalania i stosowanie technologii ograniczających emisję zanieczyszczeń do powietrza, w tym technik odpylających,

- zastosowanie odnawialnych źródeł energii,

- zmniejszenie strat przesyłu energii.

Powyższe wyliczenie sprowadza się w zasadzie do poczynienia określonych inwestycji na terenie Jeleniej Góry i wymaga przeznaczenia na ten cel znacznych środków finansowych.

\section{Zadania i kompetencje lokalnych organów administracji rządowej}

Do organów i instytucji administracji rządowej szczebla lokalnego, które realizują zadania w zakresie ochrony środowiska należą Wojewódzki Inspektor Ochrony Środowiska oraz Regionalny Dyrektor Ochrony Środowiska. Działalność lokalnych

Ibidem, s. 72.

Wyniki pomiarów powietrza dokonywanych w województwie dolnośląskim, publikowane przez Wojewódzki Inspektorat Ochrony Środowiska we Wrocławiu; http://air.wroclaw.pios.gov.pl/ (dostęp: 15.04.2013 r.). 
organów administracji rządowej jest szczególnie istotna dla utrzymania jednolitych standardów ochrony środowiska, w tym powietrza, na terenie całego kraju.

\section{Wojewódzki Inspektor Ochrony Środowiska}

Wojewódzki Inspektor Ochrony Środowiska jest organem rządowej administracji zespolonej działającym w województwie na podstawie ustawy o Inspekcji Ochrony Środowiska z 1991. ${ }^{9}$ Zasadnicze zadania Wojewódzkiego Inspektora Ochrony Środowiska w zakresie ochrony powietrza i przeciwdziałania jego zanieczyszczaniu to zadania kontrolne. Ze względu na przedmiot kontroli można wyróżnić kontrolę indywidualną (kontrola podmiotów emitujących zanieczyszczenia do powietrza) i ogólną (monitoring poziomu zanieczyszczeń w powietrzu).

Zgodnie z art. 85 ustawy prawo ochrony środowiska z $2001 \mathrm{r} .{ }^{10}$ ochrona powietrza polega na zapewnieniu jak najlepszej jego jakości, w szczególności poprzez utrzymanie poziomów substancji w powietrzu poniżej dopuszczalnych dla nich poziomów, zmniejszenie tych poziomów do dopuszczalnych, gdy nie są one utrzymywane, jak również zmniejszanie i utrzymywanie poziomów substancji w powietrzu poniżej poziomów docelowych czy celów długoterminowych. Powyższe wymaga jednak informacji o stanie zanieczyszczenia powietrza, a zatem prowadzenia stałego i systematycznego monitoringu jakości powietrza. W związku z czym ustawodawca w art. 90 p.o.ś. nałożył zatem na Wojewódzkiego Inspektora Ochrony Środowiska obowiązek prowadzenia pomiarów poziomu substancji w powietrzu na potrzeby sporządzania oceny jakości powietrza. Szczegółowe wytyczne w zakresie sporządzania tych ocen zostały określone w rozporządzeniu Ministra Środowiska w sprawie dokonywania oceny poziomów substancji w powietrzu z 3.10.2012 r. ${ }^{11}$ Oceny jakości powietrza dokonuje się $\mathrm{w}$ strefach, $\mathrm{z}$ uwzględnieniem kryteriów ustanowionych ze względu na ochronę zdrowia ludzi oraz ze względu na ochronę roślin. Strefy stanowią odpowiednio: aglomeracja powyżej 250 tys. mieszkańców, miasto (nie będące aglomeracją) o liczbie mieszkańców powyżej 100 tys. oraz pozostały obszar województwa. W województwie dolnośląskim funkcjonują cztery strefy: aglomeracja wrocławska, Wałbrzych, Legnica i strefa dolnośląska. Pomiary poziomu zanieczyszczenia powietrza w Jeleniej Górze - Cieplicach, która należy do strefy dolnośląskiej, prowadzone są poprzez automatyczną stację pomiarową zlokalizowaną w Parku Zdrojowym. Dodatkowo, w Jeleniej Górze zlokalizowane są cztery stacje pasywne. Wojewódzki Inspektor Ochrony Środowiska do 31 marca każdego roku dokonuje oceny poziomów substancji w powietrzu w danej strefie za rok poprzedni odrębnie dla każdej substancji, jak również dokonuje klasyfikacji stref. Wyniki oceny i klasy-

9 Ustawa z dnia 20.07.1991 roku o Inspekcji Ochrony Środowiska (t.j. z 28.02.2007 r., Dz.U. Nr 44, poz. 287).

10 Ustawa z dnia 27.04.2001 roku - Prawo ochrony środowiska (t.j. z 23.01.2008 r., Dz.U. Nr 25, poz. 150).

11 Rozporządzenie Ministra Środowiska z dnia 3.10.2012 r. w sprawie dokonywania oceny poziomów substancji w powietrzu (Dz.U. z 2012 r., poz. 1032). 
fikacja stref przekazywane są niezwłocznie marszałkowi województwa w celu podjęcia ewentualnych działań naprawczych, w tym sporządzenia programu ochrony powietrza w danej strefie.

Prowadzenie pomiarów powietrza jest częścią państwowego monitoringu środowiska, czyli systemu pomiarów, ocen i prognoz stanu środowiska oraz gromadzenia, przetwarzania i rozpowszechniania informacji o środowisku. Realizacja państwowego monitoringu środowiska wymaga cykliczności oraz jednolitości stosowanych metod w celu umożliwienia oceny procesów poprawy lub pogarszania się stanu środowiska naturalnego. W celu realizacji zadań informacyjnych Wojewódzcy Inspektorzy Ochrony Środowiska udostępniają na stronach internetowych wyniki dziennych, miesięcznych i rocznych pomiarów powietrza ze wskazaniem czy stężenie danej substancji w powietrzu przekroczyło dopuszczalne normy. ${ }^{12}$

\section{Regionalny Dyrektor Ochrony Środowiska}

Regionalny Dyrektor Ochrony Środowiska jest niezespolonym organem administracji rządowej, który został powołany i działa na podstawie ustawy o udostępnianiu informacji o środowisku i jego ochronie, udziale społeczeństwa w ochronie środowiska oraz ocenach oddziaływania na środowisko z 2008 r. ${ }^{13}$ Do zadań Regionalnego Dyrektora Ochrony Środowiska należy w szczególności przeprowadzanie ocen oddziaływania przedsięwzięć na środowisko (udział w tych ocenach) i wydawanie decyzji o środowiskowych uwarunkowaniach realizacji przedsięwzięć mogących istotnie oddziaływać na środowisko, jak m.in. budowa dróg i linii kolejowych. Oceny te mają na celu uwzględnianie potrzeb ochrony środowiska w planowaniu inwestycji mogących mieć negatywny wpływ na środowisko. Wpisują się zatem w politykę zrównoważonego rozwoju, polegającą na „zaspokajaniu potrzeb obecnych pokoleń bez naruszania możliwości przyszłych pokoleń do zaspokajania ich potrzeb" ${ }^{14}$ Jednocześnie wydaje się, że kompetencje Regionalnego Dyrektora Ochrony Środowiska w zakresie ochrony powietrza mają bardziej charakter zapobiegawczy, aniżeli naprawczy.

12 Wyniki pomiarów powietrza dokonywanych w województwie dolnośląskim, publikowane przez Wojewódzki Inspektorat Ochrony Środowiska we Wrocławiu; http://air.wroclaw.pios.gov.pl/ (dostęp: 15.04.2013 r.).

13 Ustawa $z$ dnia 3.10.2008 r. o udostępnianiu informacji o środowisku i jego ochronie, udziale społeczeństwa w ochronie środowiska oraz ocenach oddziaływania na środowisko (Dz.U. Nr 199, poz. 1227).

14 Raport Światowej Komisji ds. Środowiska i Rozwoju: Nasza Wspólna Przyszłość; załącznik do dokumentu A/42/427 - Rozwój i Międzynarodowa Współpraca: Środowisko; 1987. 


\section{Zadania Wojewódzkiego Funduszu Ochrony Środowiska i Gospodarki Wodnej}

Wojewódzki Fundusz Ochrony Środowiska i Gospodarki Wodnej we Wrocławiu działa od 1993 r. Do 31.12.2009 r. był wojewódzkim funduszem celowym, natomiast od 1.01.2010 r. jest samorządową osobą prawną. Działalność WFOŚiGW ukierunkowana jest na finansowe wspieranie przedsięwzięć służących ochronie środowiska, w oparciu o zasadę zrównoważonego rozwoju, m.in. w zakresie ochrony atmosfery, edukacji ekologicznej czy monitoringu środowiska. Ze środków WFOŚiGW współfinansowane są przedsięwzięcia realizowane zarówno przez jednostki samorządu terytorialnego czy organy administracji rządowej, jak również podmioty prywatne.

W 2013 r. Narodowy Fundusz Ochrony Środowiska i Gospodarki Wodnej rozpoczął realizację programu KAWKA, mającego na celu likwidację niskiej emisji wspierając wzrost efektywności energetycznej i rozwój rozproszonych odnawialnych źródeł energii. Celem programu jest zmniejszenie narażenia ludności na oddziaływanie zanieczyszczeń powietrza w strefach, w których występują znaczne przekroczenia dopuszczalnych lub docelowych poziomów stężeń zanieczyszczeń, w szczególności PM2,5, PM10 oraz CO2. Budżet programu wynosi $400 \mathrm{mln}$ zł i ma zostać rozdysponowany w formie bezzwrotnych dofinansowań inwestycji zbieżnych z celami programu. Ramy czasowe realizacji programu przewidziano na lata 20132018, przy czym alokacja środków powinna nastąpić w latach 2013-2015. Intensywność dofinansowania wynosi 90\% kosztów kwalifikowanych inwestycji, przy czym $45 \%$ będzie pochodziło ze środków WFOŚiGW, a pozostałe $45 \%$ ze środków NFOŚiGW. W ramach programu KAWKA dofinansowane mogą być przedsięwzięcia ujęte w obowiązujących programach ochrony powietrza, polegające m.in. na likwidacji lokalnych źródeł ciepła (indywidualnych kotłowni) i podłączeniu do sieci ciepłowniczej, rozbudowie sieci ciepłowniczej, termomodernizacji budynków czy zastosowaniu kolektorów słonecznych, jak również wdrażanie systemów zarządzania ruchem w miastach.

Program KAWKA może zatem stanowić jedno ze źródeł finansowania zadań inwestycyjnych, mających na celu ochronę powietrza w Jeleniej Górze w najbliższych latach. Ma to o tyle istotne znaczenie, że jak wskazano powyżej przewidziany w Programie Ochrony Powietrza dla Jeleniej Góry sprowadza się w zasadzie do poczynienia określonych inwestycji. 


\section{Zadania i kompetencje lokalnej administracji samorządowej}

Zgodnie z Europejską Kartą Samorządu Lokalnego z 15.10 .1985 r. ${ }^{15}$ generalnie odpowiedzialność za sprawy publiczne powinny ponosić przede wszystkim te organy władzy, które znajdują się najbliżej obywateli (art. 4 ust. 3). Ochrona środowiska, w tym ochrona powietrza, jako zadanie administracji publicznej niewątpliwie przekracza terytorialnie i przedmiotowo kompetencje samorządu terytorialnego. Określone zadania $\mathrm{w}$ tym zakresie, $\mathrm{z}$ uwagi na różne miejscowe uwarunkowania w poszczególnych częściach kraju, najlepiej realizowane będą jednak na szczeblu lokalnym. Wszystkie trzy ustawy samorządowe ${ }^{16} \mathrm{w}$ katalogu zadań własnych gmin, powiatów i województw przewidują ochronę środowiska. Ponadto, ustawa o samorządzie województwa (art. 11) stanowi, że województwa określają strategie rozwoju, w których uwzględniają zachowanie wartości środowiska kulturowego i przyrodniczego przy uwzględnieniu potrzeb przyszłych pokoleń. Ponadto, województwa prowadzą politykę rozwoju, na którą składa się m.in. racjonalne korzystanie $\mathrm{z}$ zasobów przyrody oraz kształtowanie środowiska naturalnego, zgodnie z zasadą zrównoważonego rozwoju. Zadania te można podzielić na zadania o charakterze organizatorskim, wykonawczym, zobowiązująco-reglamentacyjnym i kontrolno-nadzorczym. ${ }^{17}$ Szczegółowe uregulowania w zakresie kompetencji jednostek samorządu terytorialnego znalazły się w ustawach szczegółowych z dziedziny ochrony środowiska, zwłaszcza w ustawie prawo ochrony środowiska.

Wśród zadań samorządu terytorialnego wszystkich szczebli w zakresie ochrony środowiska należy wskazać zwłaszcza obowiązek tworzenia programów ochrony środowiska, nałożony na organy wykonawcze województw, powiatów i gmin w art. 17 p.o.ś. Programy te powinny wyznaczać cele ekologiczne oraz priorytety ekologiczne, poziomy celów długoterminowych, rodzaje i harmonogram działań proekologicznych, jak również wskazywać na środki niezbędne do osiągnięcia tych celów, w tym mechanizmy prawno-ekonomiczne i środki finansowe. Programy ochrony środowiska uchwalane są przez organy stanowiące samorządów poszczególnych szczebli. Ponadto, raz na dwa lata sporządzane są raporty z ich wykonania. Programy ochrony środowiska tworzone są zatem obok innych programów, takich jak strategie rozwoju i mają na celu uwzględnianie potrzeb ochrony środowiska w rozwoju społeczności lokalnych. Obowiązek tworzenia tych programów odpowiada Zasadzie nr 4 Deklaracji z Rio, ${ }^{18}$ zgodnie z którą , do osiągnięcia trwałego i zrównoważonego

15 Europejska Karta Samorządu Lokalnego, sporządzona w Strasburgu 15 października 1985 z dnia 15 października 1985 r. (Dz.U. 1994 Nr 124, poz. 607).

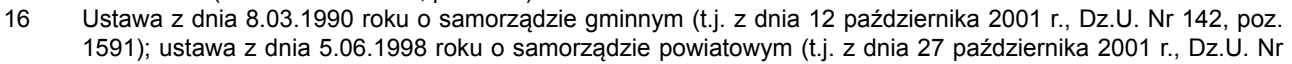
142, poz. 1592); ustawa z dnia 5.06.1998 roku o samorządzie województwa (t.j. z dnia 18 września 2001 r., Dz.U. Nr 142, poz. 1590).

17 A. Barczak, Zadania samorządu terytorialnego w zakresie ochrony środowiska, Warszawa, 2006, s. 50.

18 Deklaracja Zgromadzenia Ogólnego Organizacji Narodów Zjednoczonych z 12.08.1992 roku; A/CONF.151/26 (Vol. I). 
rozwoju konieczne jest, aby ochrona środowiska stanowiła nierozłączną część procesów rozwojowych i nie była rozpatrywana oddzielnie od nich”.

\section{Zadania i kompetencje samorządu gminy}

Gmina stanowi podstawową jednostkę samorządu terytorialnego. Gminy, poza tworzeniem i uchwalaniem programów ochrony środowiska, realizują m.in. następujące zadania z zakresu ochrony powietrza:

- uwzględnianie potrzeb ochrony powietrza w studium uwarunkowań i kierunków zagospodarowania przestrzennego oraz w miejscowych planach zagospodarowania przestrzennego (art. 72 ust. 1 pkt 6 p.o.ś.);

- finansowanie zadań w zakresie ochrony powietrza, na które mogą składać się w szczególności: usprawnienie ruchu drogowego, zakup niskoemisyjnego taboru komunikacji miejskiej, rozwój i modernizacja gminnych sieci ciepłowniczych czy też instalowanie urządzeń ograniczających emisję z gminnych ciepłowni, termomodernizacja budynków komunalnych, inwestowanie w odnawialne źródła energii itd.

Do kompetencji organów gminnych w zakresie ochrony powietrza należą m.in:

- przygotowanie przez wójta (burmistrza, prezydenta miasta) i uchwalenie przez radę gminy (miasta) studium uwarunkowań i kierunków zagospodarowania przestrzennego, jak również miejscowego planu zagospodarowania przestrzennego;

- nałożenie przez wójta (burmistrza, prezydenta miasta) w drodze decyzji na prowadzącego instalację (osobę fizyczną nie będącą przedsiębiorcą) obowiązku prowadzenia pomiarów wielkości emisji, jak również ustalenie wymagań w zakresie ochrony środowiska dotyczące instalacji;

- występowanie przez wójta (burmistrza, prezydenta miasta) w charakterze oskarżyciela publicznego $\mathrm{w}$ sprawach o wykroczenia przeciw przepisom o ochronie środowiska.

Powyższe kompetencje organów gminy w zakresie ochrony powietrza wydają się stosunkowo skromne. Realizacja zadań w zakresie ochrony powietrza na szczeblu gminy będzie zatem sprowadzała się głównie do prowadzenia proekologicznych inwestycji ukierunkowanych m.in. na obniżanie zużycia ciepła, ograniczenie emisji przy jego wytwarzaniu, rozwój lokalnej sieci ciepłowniczej oraz prowadzenie racjonalnej lokalnej polityki w zakresie transportu, w tym transportu zbiorowego. 


\section{Samorząd powiatowy}

W przeciwieństwie do zadań samorządu gminnego, zadania powiatu i przyznane staroście kompetencje mają charakter głównie reglamentacyjny i nadzorczo-kontrolny. Wydaje się, że podstawowym uprawnieniem starosty w zakresie ochrony powietrza jest wydawanie pozwoleń na wprowadzanie gazów i pyłów do powietrza oraz pozwoleń zintegrowanych. W pozwoleniach tych starosta ustala w szczególności wielkość dopuszczalnej emisji w warunkach normalnego funkcjonowania instalacji emitujących zanieczyszczenia, a także maksymalny dopuszczalny czas utrzymywania się uzasadnionych technologicznie warunków eksploatacyjnych odbiegających od normalnych. Wydając pozwolenie zintegrowane czy pozwolenie na wprowadzanie gazów i pyłów do powietrza starosta jest zobowiązany uwzględnić obowiązujące na danym terenie programy ochrony środowiska (gminny, powiatowy i wojewódzki) oraz wojewódzki program ochrony powietrza dla danej strefy, jeżeli taki został uchwalony. Starosta ma obowiązek odmówić wydania pozwolenia w przypadku, gdyby jego wydanie było niezgodne z przyjętymi programami ochrony środowiska czy ochrony powietrza. Ponadto, starosta ma obowiązek odmówić wydania pozwolenia m.in. gdyby eksploatacja instalacji powodowała przekroczenie dopuszczalnych standardów emisyjnych.

Do pozostałych kompetencji starosty $\mathrm{w}$ zakresie ochrony powietrza należą m.in.:

- nakładanie na podmioty prowadzące instalacje lub użytkowników urządzeń obowiązku prowadzenia $\mathrm{w}$ określonym czasie pomiarów wielkości emisji wykraczających poza podstawowe obowiązki prowadzenia takich pomiarów i przyjmowanie wyników pomiarów;

- ustalanie wymagań w zakresie ochrony środowiska dla instalacji, których eksploatacja nie wymaga pozwolenia;

- zobowiązanie podmiotu prowadzącego instalację do sporządzenia i przedłożenia przeglądu ekologicznego w razie stwierdzenia okoliczności wskazujących na możliwość negatywnego oddziaływania instalacji na środowisko.

W przypadku Jeleniej Góry, kompetencje starosty w powyższym zakresie realizuje prezydent miasta.

\section{Samorząd województwa}

Do zadań i kompetencji samorządu województwa w zakresie ochrony powietrza należy wyznaczanie ogólnych ram ochrony powietrza poprzez sporządzanie i uchwalanie programu ochrony środowiska, jak również programów ochrony powietrza dla danych stref w województwie. Szczególnie ten drugi rodzaj aktu prawa miejscowego ma istotne znaczenie dla ochrony powietrza. Obowiązek sporządzenia 
przez marszałka województwa programu ochrony powietrza aktualizuje się w przypadku otrzymania od Wojewódzkiego Inspektora Ochrony Środowiska oceny poziomów substancji w powietrzu w roku poprzednim oraz klasyfikacji stref, gdy z tej oceny wynika, iż zostały przekroczone dopuszczalne poziomy określonych substancji w powietrzu. Szczegółowe wymagania, jakim powinny odpowiadać programy ochrony powietrza zostały uregulowane w rozporządzeniu Ministra Środowiska z 3.10.2012 r. w sprawie programów ochrony powietrza oraz działań krótkoterminowych. ${ }^{19}$ Program ochrony powietrza powinien obejmować w szczególności następujące elementy: informacje ogólne na temat lokalizacji i topografii strefy, opis stanu jakości powietrza w strefie, przewidywany poziom substancji w powietrzu w strefie w roku prognozowanym, ewentualnie również określenie planowanych działań mających na celu osiągnięcie poziomów docelowych arsenu, kadmu, niklu i benzo(a) pirenu, które nie pociągają za sobą niewspółmiernych kosztów i dotyczą w szczególności głównych grup źródeł emisji - w przypadku opracowania programu ochrony powietrza ze względu na przekroczenia poziomu docelowego dla arsenu, kadmu, niklu i benzo(a)piranu, harmonogram rzeczowo-finansowy realizacji programu ochrony powietrza, listę działań krótkoterminowych zmierzających do ograniczenia ryzyka wystąpienia przekroczenia poziomu alarmowego, dopuszczalnego lub docelowego substancji w powietrzu.

Ponadto, marszałkowie województw są organami właściwymi w sprawach przedsięwzięć mogących zawsze znacząco oddziaływać na środowisko w rozumieniu ustawy o udostępnianiu informacji o środowisku i jego ochronie, udziale społeczeństwa w ochronie środowiska oraz o ocenach oddziaływania na środowisko.

\section{Podsumowanie}

Jak wskazała M. Suchy w opracowaniu Wojewódzkiego Inspektoratu Ochrony Środowiska ${ }^{20}$ : ,jednym z warunków realizacji przez administrację samorządową przypisanych jej zadań z zakresu ochrony środowiska jest stworzenie przez administrację państwową niezbędnych podstaw prawnych, gwarantujących możliwość stworzenia właściwych ram organizacyjnych oraz określających zasady finansowania inwestycji." Wydaje się, że ramy te w zakresie ochrony powietrza zostały stworzone w Polsce w dostatecznym zakresie. W szczególności prowadzony i stale rozwijany jest monitoring jakości powietrza, dostarczający szczegółowych informacji o stężeniu określonych substancji w powietrzu, dostarczający informacji o poziomie zanieczyszczenia powietrza i miejscach, w których zanieczyszczenia te przekraczają

19 Rozporządzenie Ministra Środowiska z 3.10.2012 roku w sprawie programów ochrony powietrza oraz działań krótkoterminowych (Dz.U. z 2012 r., poz. 1028).

20 M. Suchy, Wprowadzenie - zadania samorządu terytorialnego z zakresu ochrony środowiska, [w:] M. Suchy, J. Trzebiński (red.), Samorząd a ochrona środowiska, Wojewódzki Inspektorat Ochrony Środowiska w Rzeszowie, 2007, s. 8; http://www.wios.rzeszow.pl/cms/pliki/tekst_1.pdf (dostęp: 12.04.2013 r.). 
dopuszczalne poziomy. W połączeniu z identyfikacją źródeł zanieczyszczeń, wskazywanych w wojewódzkich programach ochrony powietrza pozwala to na podjęcie działań zmierzających do poprawy jakości powietrza na poziomie lokalnym. Działanie w zakresie ochrony środowiska podejmowane na szczeblu lokalnym mają natomiast zasadniczo charakter zadań inwestycyjnych i wymagają istotnych nakładów finansowych. Naprzeciw realizacji tych zadań wychodzi NFOŚiGW oraz wojewódzkie fundusze ochrony środowiska i gospodarki wodnej, które współfinansują inwestycje w zakresie ochrony środowiska. Jak pokazuje przykład Jeleniej Góry, ograniczenie lokalnych źródeł emisji zanieczyszczeń, przy dużej ilości zanieczyszczeń napływowych, może mieć ograniczony wpływ na poprawę jakości powietrza. Niemniej jednak podejmowanie działań w tym zakresie na większym obszarze, a nie tylko na obszarze jednego samorządu, powinno znacząco przyczynić się do poprawy jakości powietrza i przez to również standardu życia.

\section{BIBLIOGRAFIA}

Badyda A., Analiza i ocena efektów oddziaływania wybranych uciążliwości ruchu drogowego na środowisko miejskie w Warszawie, Warszawa 2006; http://bcpw.bg.pw.edu.pl/Content/2950/Praca+doktorska,+Artur+Badyda,+wersja+ostateczna.pdf (dostęp: 15.04.2013 r.).

Bank Danych Lokalnych publikowany przez Główny Urząd Statystyczny, http://www.stat.gov.pl/bdl/ app/strona.html?p_name=indeks (dostęp: 15.04.2013 r.).

Barczak A., Zadania samorządu terytorialnego w zakresie ochrony środowiska, Warszawa, 2006.

Główny Urząd Statystyczny, Ludność. Stan i struktura w przekroju terytorialnym. Stan w dniu 30 VI 2012 r.; http://www.stat.gov.pl/cps/rde/xbcr/gus/1_ludnosc_stan_struktura_30062012.pdf (dostęp: 15.04 .2013 r.).

Raport Światowej Komisji ds. Środowiska i Rozwoju: Nasza Wspólna Przyszłość; załącznik do dokumentu A/42/427 - Rozwój i Międzynarodowa Współpraca: Środowisko; 1987.

Suchy M., Wprowadzenie - zadania samorządu terytorialnego z zakresu ochrony środowiska, [w:] M. Suchy, J. Trzebiński (red.) Samorząd a ochrona środowiska, Wojewódzki Inspektorat Ochrony Środowiska w Rzeszowie, 2007; http://www.wios.rzeszow.pl/cms/pliki/tekst_1.pdf (dostęp: 12.04.2013 r.).

Wyniki pomiarów powietrza dokonywanych w województwie dolnośląskim publikowane przez Wojewódzki Inspektorat Ochrony Środowiska we Wrocławiu; http://air.wroclaw.pios.gov.p1/ (dostęp: 15.04.2013 r.). 


\section{THE ROLE OF LOCAL PUBLIC AUTHORITIES IN AIR POLLUTION PREVENTION: CASE STUDY OF JELENIA GÓRA}

The article deals with local problems concerning air pollution in Jelenia Góra. Addressing those problems serves as a basis for the analysis of the respective tasks and competences of local public authorities. An important role played by those competences is the monitoring of air pollution levels and the development of local air pollution prevention programs in cases where air pollution standards are exceeded. Analysis of the Air Pollution Prevention Program for Jelenia Góra, leads to the conclusion that undertaking the task of limiting air pollution mainly requires significant investments to be made in the following years.

Keywords: environmental protection, pollution prevention programs, air pollution 